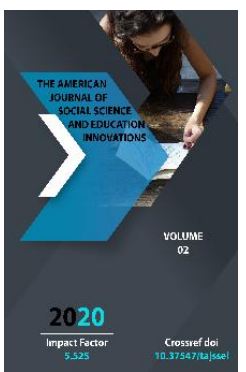

Journal Website: http://usajournalshub.c om/index,php/tajssei

Copyright: Original content from this work may be used under the terms of the creative commons attributes 4.0 licence.

\section{Socio-Geographical Features Of Crime Or Geocriminogenic Situation In Uzbekistan}

\author{
Abdulatif Abdumalikovich Kayumov \\ Candidate Of Geographical Sciences, Associate Professor, Secretary Of The Scientific- \\ Methodical Council, Republican Scientific-Practical Centre For Development Innovative \\ Methods Of Teaching Foreign Languages Under The Uzswlu, Uzbekistan
}

\title{
ABSTRACT
}

This article discusses the changes in the dynamics of the number of registered crimes, the regional characteristics of the crime and the factors related to the geocriminogenic situation. The main types of registered crimes were also studied and conclusions were drawn.

\section{KEYWORDS}

Crime geography, territory, geocriminogenic situation, types of crime, regional factors, percentage, relative, urban areas, rural areas, legal education

\section{INTRODUCTION}

Over the years of independence, the republic has taken comprehensive measures to prevent crime and combat crime, achieved positive results in maintaining law and order in the country, and significantly improved the crime situation. Earlier this year, President of the Republic of Uzbekistan Sh. Mirziyoyev said in his speech at the first session of the Senate of the Oliy Majlis, "The issue of combating crime and early prevention of crime should be in the constant focus of the Senate. In recent years, we have done a number of things to prevent and combat crime. However, there are still issues in this area that need to be addressed, "he said [2]. 
One of the important factors in the formation of the rule of law is the liberalization of the fight against crime, which is currently being carried out by the leadership of the Republic of Uzbekistan. A number of measures have been taken in Uzbekistan to create a healthy social environment, to fight against various crimes, to stabilize the conditions for people to live, rest and work in the regions. However, this complex problem has not yet been fully resolved. This requires, along with the legal framework, crime prevention and control in urban and rural areas of the country, taking into account their geographical location, demographic and environmental situation, economy, its concentration and specialization, sectors and territorial composition.

The study of crime began in the second half of the nineteenth century and became known as criminology. The word criminology is a combination of the Latin words "Crimen" "crime" and the Greek "logos" - "doctrine" (reading, study), which means "doctrine of crime" [5. 10]. In this case, the concept of crime does not mean a specific crime, but a crime in general. Crime is a social reality, the essence and content of which are territorial laws that affect the emergence and development of the geocriminogenic situation.

It should be noted that for many years almost no attention was paid to the geographical aspects of crime. Because it was only seen as an event. Today, summarizing the achievements and shortcomings of crime on the basis of scientific analysis of regional features is of great practical importance in strengthening the socio-economic and political life of Uzbekistan.

THE MAIN FINDINGS AND RESULTS
Crime is a social disorder, a negative phenomenon, and the social and economic changes that take place in a country or region have a direct impact on its status, quantity and quality, and territorial composition. Crime is a dangerous vices in society and no society has been able to come to terms with this vices. Such social ills are the exact opposite of a healthy lifestyle and the well-being of society. The geocriminogenic situation is studied more in the field of criminology and geography. If criminology studies the commission of a crime and its causes, means of prevention and the identity of the perpetrators, the various territorial features of the crime, the geographical conditions and factors affecting it relate to the geography of crime [7. 8].

The geocriminogenic situation explores the regional characteristics of the criminogenic situation, the conditions and factors influencing crimes committed in different countries or regions. Territorial factors arise from the geographical location, socioeconomic system and specialization, national, social, demographic and environmental conditions of the place [6. 25].

The geocriminogenic situation, in addition to studying the regional characteristics of crime, also examines its occurrence at different seasons and times of the year, the sociodemographic composition of offenders and the conditions and causes of specific types of crime.

The formation and development of the geocriminogenic situation is determined by changes related to the territorial aspects of the development of society. Factors influencing the crime and geocriminogenic situation can be divided into the following groups: [7]

- Socio-economic factors: the level of socioeconomic development of the region, its geographical location, city network and 
system, size of cities, functional types, level of urbanization, specialization and concentration - Demographic and demogeographic factors: population, its growth, location characteristics, migration, gender, age and national composition, employment rate, etc.

- Social and environmental factors: living conditions and lifestyle of the population, social environment and place, local community activities, family relations, population health and health, education, level of production, transport centers and nodes;

of development of social infrastructure systems, leisure use, etc.

Other types of factors: political situation, geopolitical location of the place, natural disasters, religious extremism, driving, housing conditions, etc.

According to statistics, in 2019, 46,089 crimes were registered in Uzbekistan (Table 1).

\section{Table 1}

\section{Number of registered crimes in Uzbekistan}

and dynamics

\begin{tabular}{|c|c|c|}
\hline Years & Number of crimes (person) & $\begin{array}{c}\text { The number of crimes per 1,000 } \\
\text { people }\end{array}$ \\
\hline 1990 & 88200 & 4,3 \\
\hline 2000 & 73904 & 2,9 \\
\hline 2010 & 90050 & 3,1 \\
\hline 2015 & 87946 & 2,8 \\
\hline 2016 & 87412 & 2,7 \\
\hline 2017 & 73692 & 2,3 \\
\hline 2018 & 49011 & 1,5 \\
\hline 2019 & 46089 & 1,4 \\
\hline
\end{tabular}

Table: Uzbekistan in figures 1990-2018. based on statistical collections and data from the site Stat.uz.

Between 1990 and 2000, the number of registered crimes in Uzbekistan decreased by $16.2 \%$. However, between 2000 and 2010, it increased by $21.8 \%$. In 2010-2015, crime decreased by $2.3 \%$, and in 2015-2019 by $47.6 \%$.
If we analyze the number of registered crimes in terms of quality, in 1990 the number of registered crimes per 1,000 people was 4.3, while in 2000 it was 2.9. By 2010, the number of registered crimes had risen to 3.1. In the post-2010 period, 
Doi: https://doi.org/10.37547/tajssei/Volume02Issue08-14

the number of registered crimes per 1,000 people decreased, and in 2019 the figure The geographical aspects of the total number of registered crimes in the country are as follows: $14.6 \%$ of the total number of registered crimes fall on the dropped to 1.4

city of Tashkent. At the same time, a relatively high rate is observed in Tashkent (12.7\%), Fergana (10.9\%) and Samarkand (10.7\%) regions (Table 2 ).

Table 2

\section{Geographical structure of registered crimes (2018)}

\begin{tabular}{|c|c|c|c|c|}
\hline Territories & $\begin{array}{l}\text { Number of } \\
\text { crimes, } \\
\text { person }\end{array}$ & $\begin{array}{l}\text { In relation } \\
\text { to the } \\
\text { total, in\% }\end{array}$ & $\begin{array}{c}\text { Crime per } 1,000 \\
\text { population, person }\end{array}$ & $\begin{array}{c}\text { Republican } \\
\text { average.relative, times }\end{array}$ \\
\hline Uzbekistan & 49011 & 100,0 & 1,5 & 1,000 \\
\hline $\begin{array}{l}\text { Karakalpakstan. } \\
\text { Republic }\end{array}$ & 1968 & 4,0 & 1,1 & 0,733 \\
\hline provinces: & & & & \\
\hline Andijon & 3494 & 7,1 & 1,1 & 0,733 \\
\hline Bukhara & 2972 & 6,1 & 1,6 & 1,066 \\
\hline Jizzakh & 1878 & 3,8 & 1,4 & 0,933 \\
\hline Navoi & 2067 & 4,2 & 2,1 & 1,400 \\
\hline Namangan & 3498 & 7,1 & 1,3 & 0,866 \\
\hline Samarkand & 5215 & 10,7 & 1,4 & 0,933 \\
\hline Surkhandarya & 2322 & 4,7 & 0,9 & 0,600 \\
\hline Syrdarya & 1295 & 2,6 & 1,6 & 1,066 \\
\hline Tashkent & 6240 & 12,7 & 2,2 & 1,466 \\
\hline Fergana & 5362 & 10,9 & 1,5 & 1,000 \\
\hline
\end{tabular}


Doi: https://doi.org/10.37547/tajssei/Volume02Issue08-14

\begin{tabular}{|l|c|c|c|c|}
\hline Khorezm & 1771 & 3,6 & 1,0 & 0,666 \\
\hline Kashkadarya & 2918 & 6,0 & 0,9 & 0,600 \\
\hline Tashkent & 7148 & 14,6 & 2,9 & 1,933 \\
\hline Vehicle crime & 863 & 1,8 & & \\
\hline
\end{tabular}

The table is based on the statistical collection "Social development and living standards in Uzbekistan 2015-2018" and the website Stat.uz.

The high crime rate in the above-mentioned regions is due, firstly, to the diversity of the population, secondly, the intensity of the migration process, thirdly, the high level of industrialization and high level of urbanization, fourthly, alcoholism and drug addiction among the population. It can be said that his faith has waned and that there are favorable conditions for the commission of a crime.

Currently, the share of urban population in Uzbekistan is 50.5\%, and rural - $49.5 \%$ [10]. However, crime is 6-7 times more common in cities than in rural areas. Because in a rural social environment, everyone knows each other, it is more difficult to commit a crime, hide or sell stolen things, and so on. Also, the offenses committed in the villages cause the attention and discussion of those around them. Cities, on the other hand, are usually very densely populated. They often live in multi-story, traditional neighborhood relationships, in less developed conditions. This creates a unique social environment and geocriminogenic situation.

In order to determine the criminogenic situation in the country, the number of crimes per 1,000 population was compared with the national average. In this case, the national average was equal to one, i.e $(1.5=1,000)$
(Table 2). According to the results of the comparative analysis, the criminogenic situation in Uzbekistan can be divided into 4 groups:

The first group includes the city of Tashkent, which has almost twice the national average and a very high crime rate.

The second group includes Tashkent and Navoi regions, which have almost 1.5 times the national average and a much higher crime rate.

The third group consisted of Syrdarya and Bukhara regions, which are slightly higher than the national average.

The fourth group consisted of regions with lower crime rates than the national average.

Based on the number of registered crimes, the criminogenic status of the regions can be determined. This allows for a number of reflections on crime.

According to statistics, the most common of these types of crimes are crimes committed in the field of economics. The majority of this type of crime is the looting of other people's property. It is known that these crimes pose a serious threat to society and the population. The crime of looting other people's property includes aggression, robbery, theft, fraud and other crimes. More than three-quarters of robberies are committed in cities and towns. 
These cities are densely populated and have specific difficulties in regulating and controlling social relations and relationships. Crimes of looting of other people's property are more common in public places. These types of crimes are mainly committed in the winter of the year. Because in the winter there will be more favorable conditions for such a crime. In particular, in public places in winter people are not as crowded as in summer, it gets dark early and so on.

The most common type of robbery is theft, which is the misappropriation of another's property. In 2019, $11.4 \%$ of reported crimes were thefts. The crime of theft is specific to urban and rural areas, and it comes first in both. However, as a result of strict measures taken by law enforcement agencies to protect the population and state property in recent years, the number of thefts has decreased by 1.7 times over the past 10 years, ie in 20102019. The psychology of private property and the pursuit of personal wealth through greed have become the cause of this crime. In people, such a mood is caused by the formation of a social environment, some gaps in the family and the neighborhood, and a certain indifference of the population.

The crime of fraud is one of the crimes in the field of economics. Fraud is the acquisition of another's property or right to another's property through deception or abuse of trust. In 2019, $11.8 \%$ of registered crimes were fraud. Although the number of these crimes decreased by 20\% between 2010 and 2019, its share in total crime increased.

Crimes of aggression and robbery are committed by looting the property of others and using or threatening psychological violence that is dangerous to life and health. These types of crimes are relatively high in the republic. In 2019, 1.6\% of registered crimes were crimes of aggression and robbery. The number of these types of crimes decreased by 4.6 times in 2010-2019. It turns out that these types of crime are greater in densely populated urban areas. The crime of embezzlement of private property shows that in many respects they are "urban crimes". Measures to prevent this type of crime, including the development of comprehensive tools or programs to strengthen parenting measures, are required. Because the crime of aggression is often committed by young people. It is known that in the local areas there are many unemployed people of working age. Unemployed youth are more likely to be exposed to various influences. It is advisable to develop a comprehensive action plan to prevent this type of crime without resorting to indifference.

Certain types of crimes against public safety and public order, including drug trafficking, violation of the rules of safety of movement or use of vehicles and crimes against public order, ie hooliganism, also have a relatively high incidence in the structure of crimes registered in the country. In 2019, 6.5 out of every 100 reported crimes were registered for drug-related crimes, 2 for hooliganism, and 10.8 for traffic and vehicle use violations.

It can be said that drug-related crimes were initially prevalent in cities. Crimes related to the illicit manufacture, purchase, storage, transportation, and transfer of drugs are widespread in cities. The number of registered drug-related crimes decreased by $42.3 \%$ between 2010 and 2019. However, this type of crime is much higher in Tashkent, Samarkand, Surkhandarya and Khorezm regions. It is known that these regions are the borders of Uzbekistan with Tajikistan, Kazakhstan and Turkmenistan, which encourage the involvement of citizens in the drug trade. 
Hooliganism, which is a crime against public order, is committed in connection with the intentional disregard of the rules of conduct of people, beatings, minor bodily injury or damage to another's property. This type of crime is also relatively high in the republic. In particular, in 2019, 3.5\% of registered crimes were related to hooliganism. From 2010 to 2019, the number of registered hooliganism crimes decreased by 3.4 times (70.9\%). The crime of hooliganism may be caused by insufficient application of punitive measures against public order, as well as mental disorders as a result of exposure of the population to alcohol.

In 2018, $16.8 \%$ of the registered crimes were related to traffic and vehicle use violations. In 2015-2019, this type of crime registered decreased by $3.7 \%$. It is estimated that threequarters of all road traffic accidents are caused by the fault of private car drivers. Hence, tougher penalties for these offenders are required.

The most common types of crimes against the person are crimes against life, health and sexual freedom. Intentional homicide and attempted murder accounted for $0.8 \%$ of all reported crimes and intentional grievous bodily harm accounted for $2.4 \%$ of all reported crimes. Intentional grievous bodily harm is relatively common in the type of crime against life. In 2019, 2.4 out of every 100 registered crimes in the country were intentional grievous bodily harm. According to the study, in 2010-2019, the number of intentional homicides and attempted murders in the country decreased by 2 times (59.6\%), and the number of intentional grievous bodily harm decreased by $29.7 \%$. In our opinion, the range of opportunities to prevent these crimes on the ground has expanded, as well as the role of the family, neighborhood and other public organizations in the social control of the individual.

Intentional bodily injury that is life-threatening can result in a person losing the ability to see, speak, or hear, or having their health impaired and losing a certain portion of their ability to work. If the permanent loss of at least 33\% of the victim's total capacity for work is a type of grievous bodily harm, as well as a loss of $10 \%$ to $33 \%$ of the total capacity for work, then it is a type of moderate injury.

In areas with high crime rates, not just one cause or factor, but a number of conditions and factors underlie the type of crime. As a result, certain socio-economic conditions in the regions have created a peculiar geocriminogenic situation.

\section{CONCLUSION}

According to legal experts, alcohol is the most common cause of robbery, burglary, extortion and murder with malicious intent. Therefore, the fight against crime should begin with the fight against the habit of learning to drink alcohol and creating conditions for its prevention. The fight against alcoholism is an integral part of a healthy lifestyle and the development of society, and abandoning these activities can lead to the development of criminal activity in the field. That is why it is necessary to use the power of the law and the public, especially the community, against alcoholism as a socially dangerous phenomenon.

The most experienced means of improving the geocriminogenic situation on the ground is legal education. Legal advocacy plays an important role in the development of legal education. In order to increase the legal knowledge of citizens, it is also important to create special methods of programs and presentations on legal topics that are of 
interest to them and cause more problems. One of the effective means of improving the geocriminogenic situation is to increase the socio-political activity of citizens. Sociopolitical activism should begin with the broad involvement of citizens in the affairs of state and society. If the role of governmental and non-governmental organizations in this regard is increased, the most effective results in preventing citizens from entering the path of crime can be achieved.

In the current context of the formation of new economic relations in Uzbekistan, it is possible to solve the problem of employment to some extent by developing small business and private entrepreneurship, which are based on market laws and principles and are easy to manage. Improving the geocriminogenic situation will be achieved on the basis of increasing employment in the regions. The opening of labor-intensive industries (light, food, local industry) in small and medium-sized cities is also a positive development.

\section{REFERENCES}

1. Resolution of the President of the Republic of Uzbekistan Shavkat Mirziyoyev No. PP2833 "On measures to further improve the system of crime prevention and fight against crime." Tashkent, 2017.

2. Speech of the President of the Republic of Uzbekistan Shavkat Mirziyoyev at the first session of the Senate of the Oliy Majlis. 21.01.2020.

3. Criminal Code of the Republic of Uzbekistan. Tashkent: Adolat, 2001.

4. Antonyan Yu.M. The criminal as a subject of criminological study // Questions of the problem of combating crime. Issue 34.Moscow: 1981.-p. 40.
5. Criminology. Moscow: Manuscript. 1992. p. 414.

6. Karaketov Y.M; Usmonaliev M.U. Criminological measures in the fight against crime.Tashkent: Uzbekistan. 1995. p. 228.

7. Soliev A; Raxmatov E. Current issues of criminal geography (based on materials of Tashkent region).Materials of the IV Congress of the Geographical Society of Uzbekistan. Tashkent: 1995. -p. 117-120.

8. Kayumov A.A. Socio-geographical aspects of crime in Uzbekistan. Abstract of the dissertation submitted for the degree of Candidate of Geographical Sciences. Tashkent: 2006. -p. 24.

9. Uzbekistan in figures 1990-2018 Statistical collections.

10. Statistical collection "Social development and level of life in Uzbekistan 2015-2018".

11. Information from Stat.uz website 